Images in...

\title{
Severe ureteric colic and a palpable neck node
}

\author{
Sushil Jindal, ${ }^{1}$ Shaifali Bansal, ${ }^{2}$ Ranjeet Choudhary, ${ }_{1}$ Kiran Pathak, ${ }^{3}$ Mukul Mathur, ${ }^{4}$ Rakesh Biswas ${ }^{2}$ \\ ${ }^{1}$ People's College of Medical Sciences, Bhopal, India \\ ${ }^{2}$ Department of Medicine, People's College of Medical Sciences and Research Centre, Bhopal, India \\ ${ }^{3}$ Department of Pathology, People's College of Medical Sciences, Bhopal, India \\ ${ }^{4}$ JLN Cancer Hospital, Bhopal, India
}

Correspondence to Rakesh Biswas, rakesh7biswas@gmail.com

\section{DESCRIPTION}

A 49-year-old male, hypertensive for 2 years presented with recurrent renal colic of 6 months duration. x-Ray abdomen and intravenous pyelogram showed multiple stones in both kidneys and ureters resembling beads in a necklace (figure $1 \mathrm{~A}$ and $\mathrm{B}$ ) with hydronephrotic changes. His renal function tests reflected mild renal insufficiency (serum urea 55.5 $\mathrm{mg} / \mathrm{dl}$, serum creatinine $2.5 \mathrm{mg} / \mathrm{dl}$ ) serum uric acid was 8.9 $\mathrm{mg} / \mathrm{dl}$. Serum calcium was $13.0 \mathrm{mg} / \mathrm{dl}$ and serum phosphate $2.9 \mathrm{mg} / \mathrm{dl}$. Intact plasma parathyroid hormone (PTH) was ordered which came $375.1 \mathrm{pg} / \mathrm{ml}$ against normal of $14-72$ $\mathrm{pg} / \mathrm{ml}$. There was a small, firm palpable nodule in the left lobe of thyroid measuring $1.5 \mathrm{~cm}$ in diameter. USG neck showed a well circumscribed nodule at the left lower pole of thyroid which was neither lobulated nor had any irregular margins. There was no invasion of surrounding structures. Since sestamibi has high sensitivity and specificity for localising parathyroids, a sestamibi scan was done which showed hyperfunctioning left lower parathyroid gland (figure 2).

There was no history suggestive of multiple endocrine neoplasia in the family.

Patient underwent selective parathyroidectomy of left lower parathyroid along with adenoma. Histopathology of the dissected nodular tissue was consistent with benign parathyroid adenoma (figure 3). Signs of parathyroid carcinoma, like fibrous trabecule, nuclear pleomorphism with capsular and vascular invasion, and increased mitotic figures were absent.

Postoperatively, serum calcium dropped to $7.1 \mathrm{mg}$ (which subsequently improved to normal), plasma intact PTH dropped to $3.6 \mathrm{pg} / \mathrm{ml}$. Patient remained normotensive without antihypertensive drugs. Patient underwent subsequent surgery for nephrolithiasis.

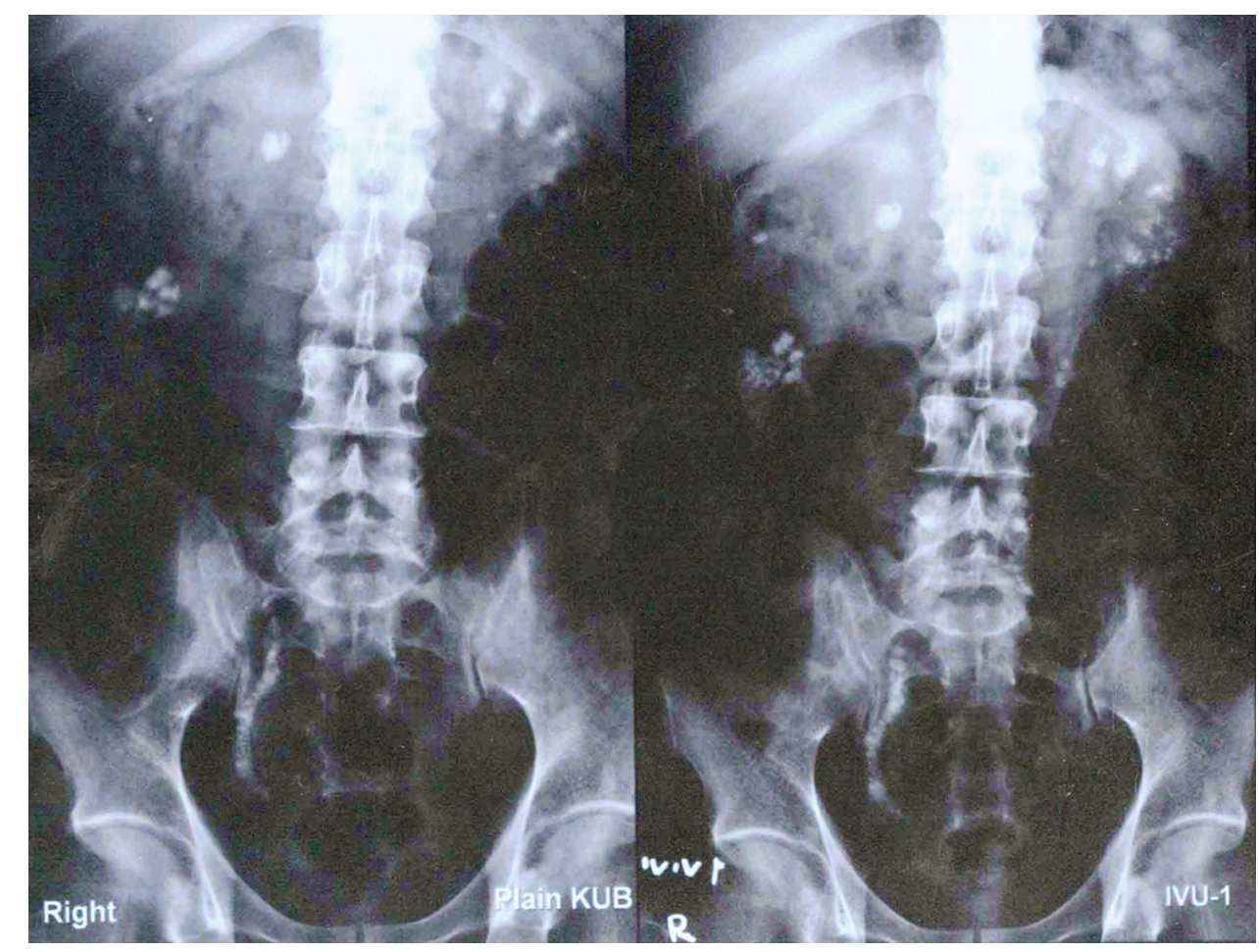

Figure 1 Multiple calculi like beads in A necklace on x-ray KUB (A) and IVP (B). 


\section{BMJ Case Reports}

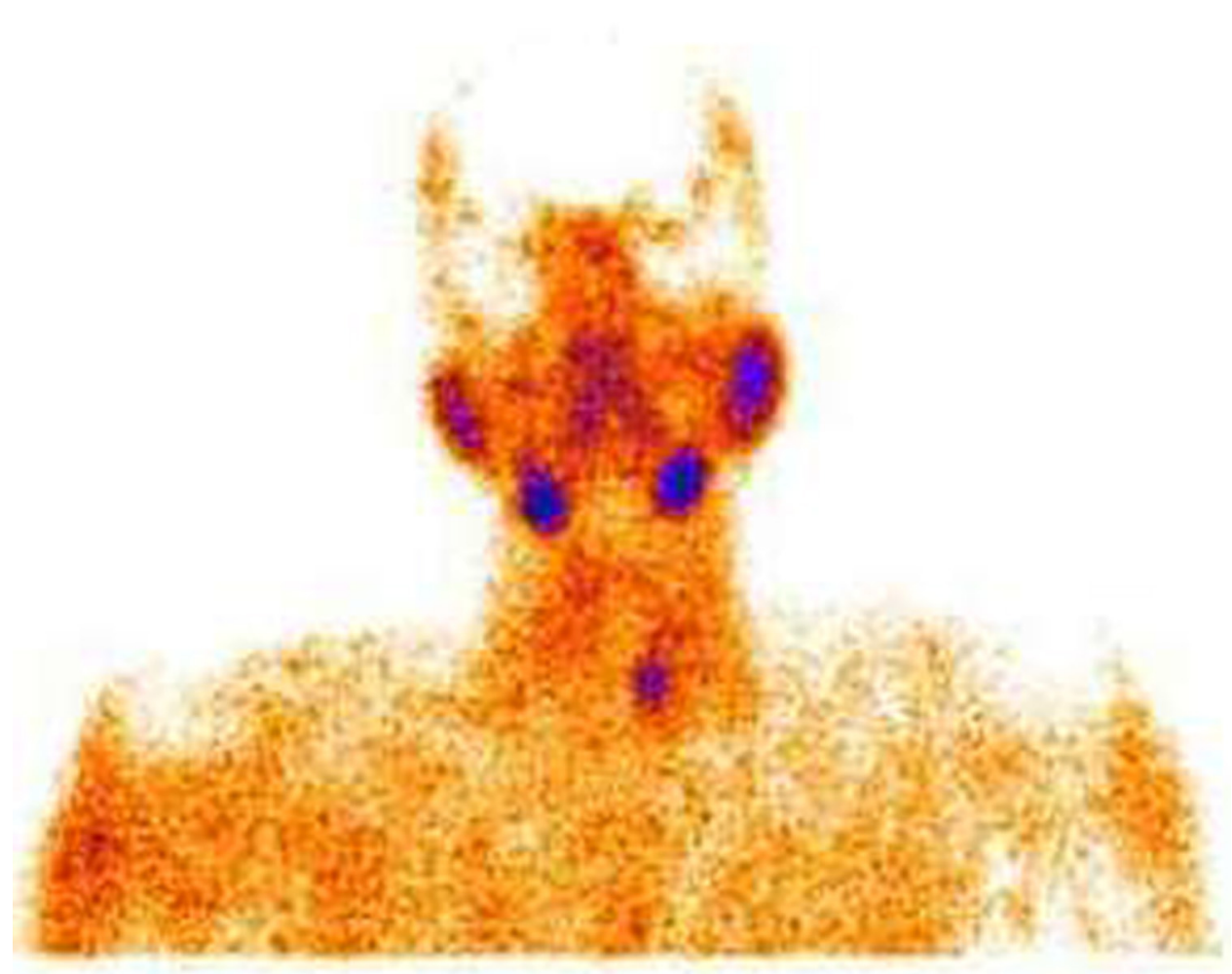

\section{ANT.2HRS DELAYED VIEW}

Figure 2 Hyperfunctioning left lower lobe nodule on sestamibi scan.

\section{DISCUSSION}

In a patient with kidney stones, an elevated serum Ca level usually means hyperparathyroidism or less frequently sarcoidosis. ${ }^{1}$

There is a fourfold increase prevalence of renal stones in patients with primary hyperparathyroidism. ${ }^{2}$ Seventy-five per cent patients undergoing surgical treatment of primary hyperparathyroidism present with nephrolithiasis. ${ }^{3}$ Diagnosis of hyperparathyroidism must be considered in patients with nephrolithiasis with hypercalcaemia.

In more than $80 \%$ patients of primary hyperparathyroidism the cause is diagnosed as benign parathyroid adenoma. Parathyroid carcinomas account for only $1-3 \%$ cases. Parathyroid malignancy is one of the least common among endocrine malignancies. Thirty to seventy-six of malignant adenomas are palpable. Palpable adenoma in this case did raise the suspicion of parathyroid malignancy. The clinical pointers to malignant adenoma are serum calcium more than 14-15 mg/dl, serum PTH more than 10 times upper limit of normal, presence of osteitis fibrosa cystica and local invasion. All these were not seen in our case. Histopathology conclusively ruled out the possibility of malignancy.
There could be a theoretical possibility of humoral hypercalcaemia of other malignancies which is usually due to secretion of PTHrP. This was ruled out by absence of symptoms and signs of any malignancy and paraneoplastic symptoms. Also, in such situations plasma intact PTH is undetectable.

Final impression: Benign parathyroid adenoma of left inferior parathyroid gland.

Acknowledgements Department of Surgery, People's College of Medical Sciences, Bhopal.

Competing interests None.

Patient consent Obtained.

\section{REFERENCES}

1. Rodman JS, Mahler RJ. Kidney stones as a manifestation of hypercalcemic disorders. Hyperparathyroidism and sarcoidosis. Urol Clin North Am 2000;27:275-85, viii.

2. Suh JM, Cronan JJ, Monchik JM. Primary hyperparathyroidism: is there an increased prevalence of renal stone disease? AJR Am J Roentgenol 2008;191:908-11.

3. Bilezikian JP, Silverberg SJ. Clinical spectrum of primary hyperparathyroidism. Rev Endocr Metab Disord 2000;1:237-45. 


\section{BMJ Case Reports}

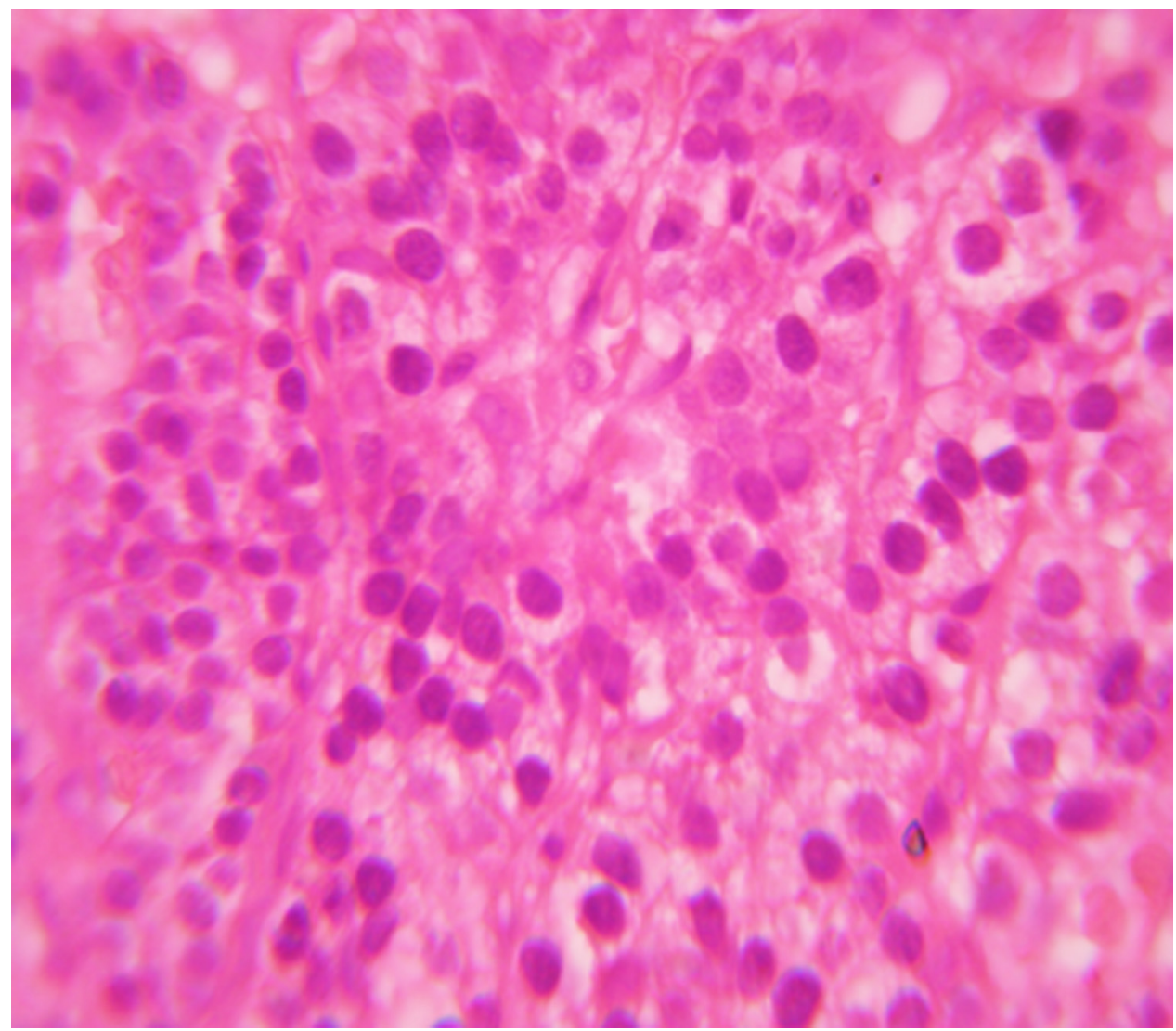

Figure 3 Histopathology of parathyroid showing parenchymal chief cells arranged in sheets cords nests within delicated capillary network.

This pdf has been created automatically from the final edited text and images.

Copyright 2010 BMJ Publishing Group. All rights reserved. For permission to reuse any of this content visit http://group.bmj.com/group/rights-licensing/permissions.

BMJ Case Report Fellows may re-use this article for personal use and teaching without any further permission.

Please cite this article as follows (you will need to access the article online to obtain the date of publication).

Jindal S, Bansal S, Choudhary R, Pathak K, Mathur M, Biswas R. Severe ureteric colic and a palpable neck node. BMJ Case Reports 2010; 10.1136/bcr.12.2009.2579, date of publication

Become a Fellow of BMJ Case Reports today and you can:

- Submit as many cases as you like

- Enjoy fast sympathetic peer review and rapid publication of accepted articles

- Access all the published articles

- Re-use any of the published material for personal use and teaching without further permission

For information on Institutional Fellowships contact consortiasales@bmjgroup.com

Visit casereports.bmj.com for more articles like this and to become a Fellow 